УДК 657

DOI: https://doi.org/10.26642/jen-2019-4(90)-161-166

\author{
Р.В. Романів, к.е.н., доц. \\ С.Р. Романів, к.е.н., доц. \\ Тернопільський національний економічний університет
}

\title{
Принципи оцінки нематеріальних активів: бухгалтерські ризики та застереження застосування
}

\begin{abstract}
Обтрунтовано актуальність дослідження в питанні формулювання принципів оиінки нематеріальних активів. Дано характеристику невизначеності інформаційного середовища та бухгалтерських ризиків. Проаналізовано вітчизняну нормативну базу з питань оцінки майна підприємства та визначено юридичні й прочедурні прогалини, які необхідно усунути для об'єктивного відображення нематеріальних активів. Охарактеризовано вплив невизначеності інформаційного середовища на реалізацію принципів оцінки нематеріальних активів та визначено бухгалтерські ризики, які при ццьому виникають. Доповнено перелік принципів оцінки нематеріальних активів у контексті складання звітності сталого розвитку підприємства. Проаналізовано вітчизняну та зарубіжну нормативну базу стосовно обліку витрат на науководослідні та дослідно-конструкторські розробки $i$ їх зв'язок з нематеріальними активами. Визначено принципи оцінки, які необхідно застосовувати до внутрішньо створених нематеріальних активів. Перспективами подальшого дослідження є питання врахування зменшення корисності нематеріальних активів при здійсненні їх оцінки.
\end{abstract}

Ключові слова: нематеріальні активи; принципи оцінки активів; бухгалтерські ризики.

Актуальність теми дослідження та постановка проблеми. Побудова процесу оцінювання активів в цілому та нематеріальних активів (НА) зокрема, відповідно до певних принципів, є необхідною умовою для об'єктивного представлення господарських процесів та їх результатів у звітності.

Проблема вартісного вимірювання облікових об'єктів загострюється в зв’язку з тим, що іiі інтеграційну функцію в узагальненні інформації щодо майнового стану підприємства, неможливо ефективно здійснювати, використовуючи старі принципи та підходи. При цьому принципам облікової оцінки та методиці іiі визначення в контексті глобалізації економіки, консолідації капіталу, слідування концепції сталого розвитку та уніфікації на цій основі фінансових показників діяльності не приділяється достатньої уваги. Крім того, на нашу думку, існують прогалини у вітчизняній нормативній базі стосовно вказаного питання, що вимагає її детального критичного аналізу.

Аналіз останніх наукових досліджень і публікацій. Питання вартісного вимірювання та бухгалтерських ризиків, які при цьому виникають, розглядались у працях I.М. Вигівської, I.М. Дрогобицького, П.О. Куцика, С.Ф. Легенчука, 3.П. Плиси, Х.І. Скоп, Я.В. Соколова та інших. Дослідження вказаних авторів стосувалися в основному фундаментальних характеристик оцінки як елемента методу бухгалтерського обліку та пов'язних з цим ризиків.

Формулювання мети статті. Основною метою статті $\epsilon$ формулювання пропозицій щодо вдосконалення нормативного та методичного забезпечення здійснення оцінки НА.

Викладення основного матеріалу дослідження. Сучасні умови ведення бізнесу характеризуються підвищеним рівнем ризику та невизначеності інформаційного середовища. В таких умовах оціночна інформація під впливом об'єктивних та суб'єктивних обставин має властивості високої волатильності, в результаті якої ії цінність втрачає свою значущість.

Категорії «ризик» і «невизначеність» тісно пов'язані між собою, проте це далеко не синоніми як можна часто зустріти в деяких публікаціях. По-перше ризик має місце тільки в тих випадках, коли необхідно приймати рішення. Інакше кажучи, саме необхідність прийняття рішення в умовах невизначеності породжує ризик. По-друге, ризик є суб'єктивним, а невизначеність - об'єктивною. Ряд авторів, розглядаючи невизначеність, дотримується подібних позицій, вважаючи, що невизначеність передбачає наявність чинників, при яких результати дій не $є$ детермінованими, а ступінь можливого впливу цих чинників на результати невідома; це неповна або неточна інформація про умови реалізації проекту; ситуація коли імовірність настання невідомих подій оцінити наперед неможливо; це неповне або неточне уявлення про значення різних параметрів в майбутньому, яке породжене різними причинами i, перш за все, неповною або/і неточною інформацією про умови реалізації рішень, в тому числі пов'язаних з витратами [8].

За можливістю отримання інформації можна виокремити два види невизначеності: абсолютна, обумовлена неможливістю отримання в майбутньому інформації про внутрішні властивості об'єкта управління навіть після додаткового і більш глибокого його вивчення; тимчасова, пов'язана 3 неповною

(C) Р.В. Романів, С.Р. Романів, 2019 
інформацією про об'єкт в даний момент часу. Цю невизначеність можна зменшити після отримання додаткової інформації при розширенні джерел її отримання [12, с. 35].

Як зазначає проф. С.Ф. Легенчук, невизначеність в обліку має суб'єктивний та об'єктивний характер. Об'єктивна невизначеність в обліку викликана дією певних факторів, природа яких в цілому $\epsilon$ невідомою. За умов об'єктивної невизначеності розподіл результатів у групі випадків відомий завдяки апріорним розрахункам чи зі статистичних даних минулого досвіду. Суб'єктивна невизначеність в обліку 3 позицій бухгалтера породжується наявністю обмеженого масиву інформації, на основі якої приймається рішення. За умов суб'єктивної невизначеності відсутня можливість сформувати будь-яку групу випадків, оскільки ситуація (об'єкт), що виникла, є унікальною. Прикладом суб'єктивної невизначеності може бути оцінка нематеріальних активів, аналоги яких є відсутніми на активному ринку [5, c. 221].

Невизначеність породжує і бухгалтерські ризики. Професійні ризики в процесах інтерпретації фактів бухгалтерським персоналом виникають на різних етапах обробки облікової інформації, зокрема, на етапі здійснення оцінки й вимірювання та реєстрації даних, перетворення їх в бухгалтерську інформацію, передача такої інформації для інтерпретації фактів господарського життя управлінського персоналу та формування облікової i нефінансової звітності. Вигівська I. вважає, що бухгалтерські ризики випливають 3 підприємницьких ризиків, під якими розуміється імовірність втрати підприємством своїх активів, недоотримання доходів, перевищення витрат запланованої величини [1, с. 41].

Відповідно до існуючого законодавства, підгрунтям визнання підприємницьких ризиків у системі бухгалтерського обліку є принцип обачності, який передбачає при відображенні наданої у звітності інформації запобігання завищенню оцінки активів та доходів чи заниженню оцінки витрат та зобов'язань підприємства, спричинених існуванням факторів невизначеності. Зокрема, вплив невизначеності має враховуватися підприємством при визнанні доходу і витрат, участі у спільній діяльності, оцінці активів та їі зміни, обліку фінансових інструментів [2, с. 89]. Для оцінки НА бухгалтерський ризик слід визначити як ступінь невизначеності, яка пов'язана з отриманням очікуваних в майбутньому доходів від володіння НА або ризик нереалізації прогнозів. При певному рівні очікуваних майбутніх доходів вартість НА буде більшою, якщо імовірність отримання доходів буде вищою. Інакше кажучи, при певному рівні очікуваного доходу, або грошового потоку від володіння НА, чим нижчим буде ризик, тим вищою поточна вартість таких активів.

Усуненню негативного впливу інформаційної невизначеності у здійсненні оціночної діяльності сприятиме вироблення певних принципів її здійснення, хоча навіть і в цьому випадку бухгалтерські ризики не будуть повністю нівельовані.

Принципи вартісного вимірювання мають являти собою ряд базових умов, що лежать в основі процесу формування вартості активів. Їх дотримання має забезпечити репрезентативність облікової інформації, яку можна трактувати як добросовісне (на основі професійного судження бухгалтера) визначення вартості активу, що $є$ повним та суттєвим як для його характеристики, так і для прийняття рішень різними групами зацікавлених осіб.

Повнота стосовно оцінки активу означає врахування максимальної кількості чинників, які здатні забезпечити реальний прогноз майбутніх доходів. Суттєвість стосовно оціночної інформації означає, що при іiі формуванні були враховані всі чинники та інформаційні ризики, пропуск або викривлення яких могло б негативно вплинути на ефективність прийнятих рішень.

В Законі України «Про оцінку майна, майнових прав та професійну оціночну діяльність в Україні», зокрема в статті 3 зазначено, що оцінюватися можуть як об’єкти в матеріальній формі, так i нематеріальні активи, в тому числі об'єкти права інтелектуальної власності. При цьому майновими правами, які можуть оцінюватися, визнаються будь-які права, пов'язані з майном, відмінні від права власності, у тому числі права, які є складовими частинами права власності (права володіння, розпорядження, користування), а також інші специфічні права (права на провадження діяльності, використання природних ресурсів тощо) [3]. У Національному стандарті № 1 «Загальні засади оцінки майна і майнових прав» принципами визначені покладені в основу методичних підходів основні правила оцінки майна, які відображають соціально-економічні фактори та закономірності формування вартості майна [10]. При цьому в статті 4 зазначеного документа як такі принципи визначено принципи корисності, попиту і пропонування, заміщення, очікування, граничної продуктивності внеску, найбільш ефективного використання. В цьому документі зазначені принципи вказані як універсальні, проте їх застосування має деякі специфічні особливості щодо НА. На жаль, в Національному стандарті № 4 «Оцінка майнових прав інтелектуальної власності» [11] нічого не зазначено про специфіку їх застосування.

Для зручності застосування вказані принципи доцільно розділити на кілька груп (табл. 1). Крім того, пропонуємо доповнити вказані групи принципами, які не знайшли відображення у вітчизняній нормативній базі, але були б доречними в процесі оцінювання активів в цілому і НА зокрема. 
Однак зазначений перелік принципів оцінки, на нашу думку, є неповним. Зокрема, залишаються питання щодо оцінки новостворених НА на самому підприємстві в результаті здійснення витрат на НДДКР.

Світова облікова практика виробила різні позиції стосовно такої ситуації. Нормативна база зарубіжних країн передбачає кілька альтернативних підходів. Країни, які дотримуються правил GAAP застосовують Положення SFAS № 2 «Облік витрат на НДДКР», де визначено, що такі витрати мають бути списані в поточному періоді в міру їх виникнення. Інакше кажучи, їх капіталізація не дозволяється, за виключенням витрат на НДДКР, що виникли у процесі виконання зобов'язань за договором $з$ третьою стороною, чи до витрат, які є специфічними для видобувних галузей промисловості. Вказаного підходу дотримуються в США і Канаді.

Наближеним за змістом стосовно обліку зазначених витрат є положення параграфу 248 Німецького комерційного кодексу, де зазначається, що визнання необоротних нематеріальних активів, що не були придбані у третьої сторони, не дозволяється. Витрати на їх капіталізацію дозволено лише тоді, коли відбулося придбання за плату ззовні. В іншому випадку витрати, пов'язані зі створенням таких активів, мають бути відразу списані. Це загальне правило засноване на принципі консерватизму [13, с. 243].

3 нашої точки зору, превалювання принципу консерватизму в нормативній обліковій практиці цих країн не сприяє об'єктивному відображенню інформації стосовно НА, оскільки багато таких активів, зокрема патенти, виникають якраз внаслідок внутрішніх розробок. В країнах $\mathrm{CC}$, де застосовують МСБО, облік витрат на НДДКР регулюється стандартом МСБО (IAS) 38 «Нематеріальні активи». Зазначений документ передбачає розділення витрат на «дослідження» і «розробку». Пункт 54 прямо вказує, що в процесі дослідження не може виникнути ніякий НА, тому і витрати мають бути списані у поточному періоді.

Пункт 57 вказаного документа допускає створення НА за наявності у суб'єкта господарювання таких умов: а) технічну можливість завершити створення НА так, щоб він був придатний до використання або продажу; б) свій намір завершити створення НА та використовувати або продати його; в) свою здатність використовувати або продати НА; г) як нематеріальний актив генеруватиме ймовірні майбутні економічні вигоди.

Таблиия 1

Ризики та застереження застосування загальних принципів оцінки стосовно нематеріальних активів

\begin{tabular}{|c|c|c|}
\hline $\begin{array}{c}\text { Принцип } \\
\text { оцінки }\end{array}$ & Сутність принципу & $\begin{array}{c}\text { Обмеження та застереження } \\
\text { застосування принципу стосовно } \\
\text { нематеріальних активів }\end{array}$ \\
\hline 1 & 2 & 3 \\
\hline \multicolumn{3}{|c|}{ I група. Принципи, що грунтуються на уявленнях власника } \\
\hline $\begin{array}{l}\text { 1.1. Принцип } \\
\text { корисності (існує } \\
\text { в нормативних } \\
\text { документах) }\end{array}$ & $\begin{array}{l}\text { Будь-який актив має свою вартість } \\
\text { тільки за умови корисності його для } \\
\text { потенційного власника протягом } \\
\text { певного часу }\end{array}$ & $\begin{array}{l}\text { Один і той же актив може бути } \\
\text { неоднаково цінним для різних власників }\end{array}$ \\
\hline $\begin{array}{l}\text { 1.2. Принцип } \\
\text { заміщення (існує в } \\
\text { нормативних } \\
\text { документах) }\end{array}$ & $\begin{array}{l}\text { Максимальна вартість активу на } \\
\text { відкритому ринку не може бути } \\
\text { більшою за найменшу ціну, за яку } \\
\text { може бути придбаний або створений } \\
\text { актив } 3 \text { аналогічними споживчими } \\
\text { властивостями }\end{array}$ & $\begin{array}{l}\text { Унікальність багатьох видів НА } \\
\text { ускладнює пошук аналогу, що створює } \\
\text { ризик викривлення реальної оцінки }\end{array}$ \\
\hline $\begin{array}{l}\text { 1.3. Принцип } \\
\text { очікування (існує } \\
\text { в нормативних } \\
\text { документах) }\end{array}$ & $\begin{array}{l}\text { Ринкова вартість об’єкта залежить від } \\
\text { економічних вигід, які очікує } \\
\text { отримати власник }\end{array}$ & $\begin{array}{l}\text { Ріст невизначеності } \\
\text { середовища і зростання } \\
\text { ризиків ууалтерських } \\
\text { майбутніх дохладів }\end{array}$ \\
\hline \multicolumn{3}{|c|}{ II група. Принципи, пов’язані з особливостями об’єкту оцінки і його експлуатації } \\
\hline $\begin{array}{l}\text { 2.1. Принцип } \\
\text { додаткового } \\
\text { внеску } \\
\text { (пропозиція) }\end{array}$ & $\begin{array}{l}\text { Ринкова вартість активу буде } \\
\text { збільшуватися при додаванні нового } \\
\text { чинника, здатного генерувати дохід }\end{array}$ & $\begin{array}{l}\text { Сума, затрачена на створення } \\
\text { додаткового чиннику, не завжди може } \\
\text { бути адекватною ринковій вартості НА } \\
\text { (наприклад, вдосконалення патенту на } \\
\text { винахід) }\end{array}$ \\
\hline $\begin{array}{l}\text { 2.2. Принцип } \\
\text { додаткової } \\
\text { продуктивності } \\
\text { (пропозиція) }\end{array}$ & $\begin{array}{l}\text { Додаткова продуктивність } \\
\text { визначається чистим доходом після } \\
\text { компенсації всіх витрат }\end{array}$ & $\begin{array}{l}\text { Виникає, наприклад, при володінні правами } \\
\text { користування природними ресурсами (в } \\
\text { певному місці краще розвинена логістика). } \\
\text { Високий бухгалтерський ризик стосовно } \\
\text { прогнозування суми всіх витрат протягом } \\
\text { терміну використання НА }\end{array}$ \\
\hline
\end{tabular}




\begin{tabular}{|c|c|c|}
\hline \multicolumn{3}{|r|}{ Закінчення табл. } \\
\hline 1 & 2 & 3 \\
\hline $\begin{array}{l}\text { 2.3. Принцип } \\
\text { граничної } \\
\text { продуктивності } \\
\text { внеску (існує в } \\
\text { нормативних } \\
\text { документах) }\end{array}$ & $\begin{array}{l}\text { Зміна різних виробничих чинників по } \\
\text { різному впливає на вартість активу. } \\
\text { Зокрема, враховується вплив на } \\
\text { вартість таких чинників, як праця, } \\
\text { управління, капітал та земля, що є } \\
\text { пропорційним їх внеску у загальний } \\
\text { дохід }\end{array}$ & $\begin{array}{l}\text { Здійснення додаткових витрат на } \\
\text { підтримання і вдосконалення активу } \\
\text { тільки в певний період дозволяє } \\
\text { досягнути граничної продуктивності, } \\
\text { після чого приріст додаткової } \\
\text { вартості припиняється (наприклад, } \\
\text { патент на випуск певної продукції). } \\
\text { Потрібно співвимірювати вартість } \\
\text { НА з життєвим циклом продукції }\end{array}$ \\
\hline \multicolumn{3}{|c|}{ III група принципів. Принципи, обумовлені впливом оточуючого середовища } \\
\hline $\begin{array}{l}\text { 3.1. Принцип } \\
\text { залежності } \\
\text { (пропозиція) }\end{array}$ & $\begin{array}{l}\text { Вартість активу залежить від } \\
\text { характеру оточуючого середовища }\end{array}$ & 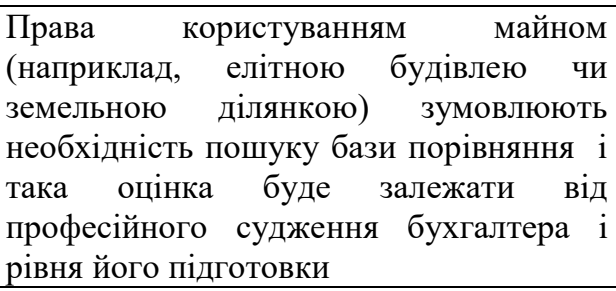 \\
\hline $\begin{array}{l}\text { 3.2. Принцип попиту } \\
\text { та пропонування } \\
\text { (існує в нормативних } \\
\text { документах) }\end{array}$ & $\begin{array}{l}\text { Під час проведення оцінки } \\
\text { враховуються ринкові коливання } \\
\text { цін на подібний актив та інші } \\
\text { фактори, що можуть призвести до } \\
\text { змін } \quad \text { у } \\
\begin{array}{l}\text { пропонування та та пвідношенні } \\
\text { подібний актив }\end{array}\end{array}$ & $\begin{array}{l}\text { Велика кількість НА має унікальний } \\
\text { характер і стосовно них є відсутнім } \\
\text { поняття «активного ринку» }\end{array}$ \\
\hline $\begin{array}{l}\text { 3.3. Принцип } \\
\text { відповідності } \\
\text { (пропозиція) }\end{array}$ & 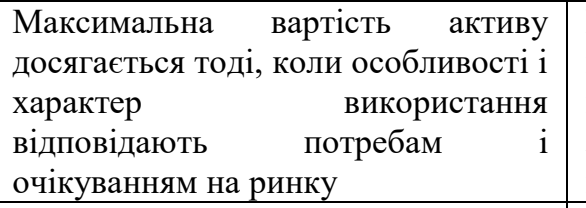 & $\begin{array}{l}\text { Права на торгову марку та комерційні } \\
\text { позначення вимагають постійних } \\
\text { капіталовкладень. Сума затраченого не } \\
\text { завжди може бути адекватною ринковій } \\
\text { вартості НА }\end{array}$ \\
\hline $\begin{array}{c}\text { 3.4. Принцип } \\
\text { найбільш } \\
\text { ефективного } \\
\text { використання (iснує } \\
\text { в нормативних } \\
\text { документах) } \\
\end{array}$ & $\begin{array}{l}\text { Враховується залежність ринкової } \\
\text { вартості активу від його найбільш } \\
\text { ефективного використання, під } \\
\text { яким розуміється використання } \\
\text { активу, в результаті якого вартість } \\
\text { об'єкта оцінки є максимальною } \\
\end{array}$ & 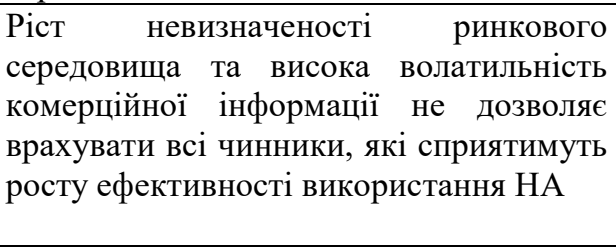 \\
\hline
\end{tabular}

Серед іншого, суб’єктові господарювання слід довести існування ринку для продукції НА чи для самого НА або (якщо його використовуватимуть внутрішньо) корисність нематеріального активу; г) наявність відповідних технічних, фінансових та інших ресурсів для завершення розробки та використання чи продажу НА; д) свою здатність достовірно оцінити видатки, які належать до НА протягом його розробки [7]. Дуже схожа позиція відображена і у вітчизняному П(С)БО 8 «Нематеріальні активи».

Порівняння нормативної бази показує, що країни, які використовують МСБО, мають більше альтернативних варіантів при прийнятті рішення стосовно обліку витрат на НДДКР. Тому, на нашу думку, при здійсненні оцінки новостворених НА потрібно дотримуватися принципу розділення витрат на дослідження і на розробку. Такий підхід дозволить вдосконалити процес комерціалізації НА. Під комерціалізацією НА С.Ф. Легенчук розуміє всі можливі варіанти (прямі і непрямі) одержання економічних вигід від їх власного використання або від використання іншими суб'єктами [6, с. 19].

Аналіз вітчизняної нормативної бази, яка стосується оцінки майна, засвідчив відсутність принципів щодо ситуації, коли всі обставини свідчать, що НА змінює свою вартість. До сьогодні залишається невирішеним на методологічному та методичному рівнях процес переоцінки НА. Характерною особливістю переоцінки нематеріальних активів є те, що зовнішні суб'єкти оціночної діяльності не завжди можуть об'єктивно визначити їхню справедливу вартість, що пов'язано з відсутністю аналогів для порівняння на ринку та складністю застосування витратного (враховуючи специфіку технологічного процесу) і дохідного (враховуючи невизначеність терміну корисного використання) підходів до оцінки нематеріальних активів [9, с. 139]. 
Сучасним трендом у формуванні системи звітності на підприємстві є складання Звітності сталого розвитку, де відображаються в тому числі і показники соціальної відповідальності бізнесу.

Експерти Всесвітнього банку визначили стійкий (сталий) розвиток як процес управління сукупністю активів, спрямований на збереження і розширення можливостей компанії. Активи в даному визначенні включають не тільки традиційний фізичний капітал, але і природній та людський. Щоб бути стійким, розвиток має забезпечити ріст у часі всіх цих активів.

За даними американської аналітичної організації Conference Board у компаній, які впроваджують концепцію сталого розвитку, спостерігається вищими дохід на інвестований капітал (на 9,8 \%), дохід 3 активів (на 3,55 \%) і прибуток (63,5 \%), ніж в компаній, які ігнорують вказану концепцію. Нефінансова звітність дозволяє сформувати імідж прозорої компанії і завоювати таким чином довіру зацікавлених сторін. Дослідження засвідчили, що 82 \% представників північноамериканських компаній і $66 \%$ європейських компаній розглядають транспарентність організації як вирішальний аспект репутації компанії і спираються на даний показник при пошуку шляхів капіталовкладення [4].

У зв'язку з необхідністю відображення інформації у звітності сталого розвитку, пропонуємо ввести додаткову групу принципів оцінки «Принципи, обумовлені впливом на соціосередовище і екологію». Особливості застосування вказаних принципів до оцінки активів полягатиме у коригування їх вартості на величину соціально-екологічного ефекту підприємства від їх володіння та використання. При цьому слід враховувати і етнічні та релігійні особливості регіону, де випускається та реалізується продукція, пов'язана 3 такими НА. Зокрема, якщо ми говоримо про такий нематеріальний актив, як володіння правами користування природними ресурсами (право на розробку надр), то цілком логічним $\epsilon$ врахування суми витрат на екологію, які підприємство зобов'язане здійснювати на постійній основі. Жорстке екологічне законодавство європейських країн і країн Північної Америки передбачає також здійснювати капітальні витрати на відновлення території, де проводилися такі розробки. Крім того, еколого-соціальна політика зазначених підприємств, як правило, спрямована на збільшення витрат на соціальні та гуманітарні програми територіальних громад.

Володіння фармацевтичними компаніями рядом патентів на розробку новітніх медичних препаратів може йти у розріз з релігійними переконаннями територіальних громад і навіть цілих держав, де знаходять офіси таких підприємств. Такі факти теж необхідно враховувати при здійсненні оцінки НА.

Висновки та перспективи подальших досліджень:

1. Для репрезентативності облікової інформації, забезпечення ії повноти та суттєвості має бути сформована більш досконала система принципів оцінювання НА, яку необхідно імплементувати у вітчизняну нормативну базу. Вказані принципи сприятимуть зменшенню бухгалтерського ризику i зростанню повноти та суттєвості оціночної інформації як для об'єктивної характеристики зазначених активів, так і для прийняття рішень різними групами зацікавлених осіб.

2. У зв'язку з тим, що частина НА створюється у результаті здійснення НДДКР, необхідно дотримуватися принципу розділення витрат на дослідження і на розробку. Такий підхід дозволить удосконалити процес комерціалізації НА.

3. Світовий тренд щодо збільшення кількості підприємств, які складають звітність сталого розвитку, висуває перед обліковою службою необхідність дотримання специфічних принципів оцінювання, які б враховували вплив НА на навколишнє екологічне та соціальне середовища.

Подальшим напрямом дослідження є вдосконалення процесу переоцінки НА, визначення критеріїв їх знецінення та відображення таких результатів в обліковій роботі.

\section{Список використаної літератури:}

1. Вигівська I.M. Сутність і класифікація професійних ризиків облікового персоналу / I.M. Вигівська // Вісник ЖДТУ. - 2010. - № 4. - С. 40-43.

2. Гнилицька Л.В. Інформаційне забезпечення ризиками підприємницької діяльності: обліковий аспект / Л.В. Гнилицька // Економічні інновації. - 2014. - № 57. - С. 88-100.

3. Про оцінку майна, майнових прав та професійну оціночну діяльність в Україні : Закон України № 2658-III від 12.07.2001 р. [Електронний ресурс]. - Режим доступу : https://zakon.rada.gov.ua/laws/show/2658-14.

4. Корпоративная социальная ответственность - новая философия бизнеса [Электронный ресурс]. - Режим доступа : http:// veb.ru>common/upload/kso/ksobook2011.pdf.

5. Легенчук С.Ф. Теорія і методологія бухгалтерського обліку в умовах постіндустріальної економіки : монографія / С.Ф. Легенчук. - Житомир : ЖДТУ, 2010. - 652 с.

6. Легенчук С.Ф. Проблеми бухгалтерського обліку комерціалізації нематеріальних активів / С.Ф. Легенчук // Вісник ЖДТУ. - 2016. - № 1. - С. 18-23.

7. Міжнародний стандарт бухгалтерського обліку 38 (МСБО 38) «Нематеріальні активи» [Електронний pecypc]. - Режим доступу : https://zakon.rada.gov.ua/laws/show/929_050.

8. Дубров А.М. Моделирование рисковых ситуаций в экономике и бизнесе / А.М. Дубров, Б.А. Лагоша, Е.Ю. Хрусталёв ; под. ред. Б.А. Лагоши. - М. : Финансы и статистика, 2000. - 176 с. 
9. Облікова концепція управління вартістю нематеріальних активів підприємства : монографія / П.О. Куцик, I.М. Дрогобицький, 3.П. Плиса, Х.І. Скоп. - Львів : Растр-7, 2016. - 268 с.

10. Про затвердження Національного стандарту № 1 «Загальні засади оцінки майна і майнових прав : Постанова Кабінету Міністрів України : № 1440 від 10 вересня 2003 р. [Електронний ресурс]. - Режим доступу : https://zakon.rada.gov.ua/laws/show/1440-2003.

11. Про затвердження Національного стандарту № 4 «Оцінка майнових прав інтелектуальної власності» : Постанова Кабінету Міністрів України : № 1655 від 29 листопада 2006 р. [Електронний ресурс]. - Режим доступу : https://zakon.rada.gov.ua/laws/show/1185-2007.

12. Романів Р.В. Невизначеність інформаційного середовища та їі вплив на бухгалтерські ризики / Р.В. Романів // Стан та перспективи розвитку бухгалтерського обліку в умовах глобалізації : монографія / 3.В. Задорожний, Я.Д. Крупка, В.А. Дерій та ін. ; за ред. З.В. Задорожного. - Тернопіль : ТНЕУ, 2018. - 192 с.

13. Шрайбер С. Облік витрат на НДДКР: відмінності та подібності між US GAAP, МСФЗ і німецьким комерційним кодексом / С.Шрайбер // Журнал європейської економіки. - 2006. - № 4. - С. 411-427.

\section{References:}

1. Vygivs'ka, I.M. (2010), «Sutnist' i klasyfikacija profesijnyh ryzykiv oblikovogo personalu», Visnyk ZhDTU, No. 4, pp. $40-43$

2. Gnylyc'ka, L.V. (2014), «Informacijne zabezpechennja ryzykamy pidpryjemnyc'koi' dijal'nosti: oblikovyj aspekt», Ekonomichni innovacii', No. 57, pp. 88-100.

3. Verhovna Rada Ukrai'ny (2001), «Pro ocinku majna, majnovyh prav ta profesijnu ocinochnu dijal'nist' v Ukrai'ni», zakon, No. 2658-III, vid 12 lypnja, [Online], available at: https://zakon.rada.gov.ua/laws/show/2658-14

4. «Korporativnaja social'naja otvetstvennost' - novaja filosofija biznesa» (2011), [Online], available at: http://veb.ru>common/upload/kso/ksobook2011.pdf

5. Legenchuk, S.F. (2010), Teorija i metodologija buhgalters'kogo obliku v umovah postindustrial'noi' ekonomiky, monografija, ZhDTU, Zhytomyr, $652 \mathrm{p}$.

6. Legenchuk, S.F. (2016), «Problemy buhgalters'kogo obliku komercializacii' nematerial'nyh aktyviv», Visnyk ZhDTU, No. 1, pp. 18-23.

7. Ministerstvo finansiv Ukrai'ny, «Mizhnarodnyj standart buhgalters'kogo obliku 38 (MSBO 38) «Nematerial'ni aktyvy», [Online], available at: https://zakon.rada.gov.ua/laws/show/929_050

8. Dubrov, A.M., Lagosha, B.A. and Hrustaljov, E.Ju. (2000), Modelirovanie riskovyh situacij v jekonomike i biznese, in Lagosha, B.A. (ed.), Finansy i statistika, Moskva, 176 p.

9. Kucyk, P.O., Drogobyc'kyj, I.M., Plysa, Z.P. and Skop, H.I. (2016), Oblikova koncepcija upravlinnja vartistju nematerial'nyh aktyviv pidpryjemstva, monografija, Rastr-7, L'viv, $268 \mathrm{p}$

10. Kabinet Ministriv Ukrai'ny (2003), «Pro zatverdzhennja Nacional'nogo standartu № 1 «Zagal'ni zasady ocinky majna i majnovyh prav», Postanova, No. 1440, vid 10 veresnja, [Online], available at: https://zakon.rada.gov.ua/laws/show/1440-2003

11. Kabinet Ministriv Ukrai'ny (2006), «Pro zatverdzhennja Nacional'nogo standartu № 4 «Ocinka majnovyh prav intelektual'noi' vlasnosti», postanova, No. 1655, vid 29 lystopada, [Online], available at: https://zakon.rada.gov.ua/laws/show/1185-2007

12. Romaniv, R.V., Zadorozhnyj, Z.V., Krupka, Ja.D., Derij, V.A. and others (2018), «Nevyznachenist' informacijnogo seredovyshha ta i'i' vplyv na buhgalters'ki ryzyky», Stan ta perspektyvy rozvytku buhgalters'kogo obliku v umovah globalizacii', monografija, in Zadorozhnyj, Z.V. (ed.), TNEU, Ternopil', 192 p.

13. Shrajber, S. (2006), «Oblik vytrat na NDDKR: vidminnosti ta podibnosti mizh US GAAP, MSFZ i nimec'kym komercijnym kodeksom», Zhurnal jevropejs'koi' ekonomiky, No. 4, pp. 411-427.

Романів Ростислав Володимирович - кандидат економічних наук, доцент кафедри обліку i оподаткування Тернопільського національного економічного університету.

Наукові інтереси:

- розвиток теорії бухгалтерського обліку;

- облік та аналіз використання нематеріальних активів.

E-mail: rvr.rom@gmail.com.

ORCID: 0000-0003-0118-2865

Романів Світлана Романівна - кандидат економічних наук, доцент кафедри економічної експертизи та аудиту бізнесу Тернопільського національного економічного університету.

Наукові інтереси:

- розвиток теорії бухгалтерського обліку;

- розвиток теорії контролю та економічної експертизи.

E-mail: tril_sr@ukr.net.

ORCID: 0000-0003-4123-2046 